\title{
High rate of aspirin resistance in advanced kidney failure: does it matter?
}

\author{
Tomasz Stompór ${ }^{1}$, Anetta Undas ${ }^{2}$ \\ 'Department of Nephrology, Hypertension and Internal Medicine, University of Warmia and Mazury, Olsztyn, Poland \\ ${ }^{2}$ Institute of Cardiology, Jagiellonian University Medical College, John Paul II Hospital, Krakow, Poland
}

We have read with keen interest a paper by Aksu et al. [1]. The problem addressed in this article is relevant, since aspirin is abundantly used in high risk patients to prevent cardiovascular (CV) disease; in addition many other anticoagulant and antiplatelet agents emerged recently and their clinical significance in $\mathrm{CV}$ diseases is a subject of ongoing discussion $[2,3]$. Aksu et al. [1] have reported that the prevalence of aspirin resistance (AR) increases in chronic kidney disease (CKD) stages 4 and 5 (estimated glomerular filtration rate [eGFR] $<30 \mathrm{~mL} / \mathrm{min} / 1.73 \mathrm{~m}^{2}$, with $86 \%$ of patients on haemodialysis), as compared to the remaining 3 groups (i.e. eGFR > 90 [control], eGFR 60-90 [stage 2] and eGFR 30-60 mL/min/1.73 $\mathrm{m}^{2}$ [stage 3]). Interestingly, they observed that AR is weakly correlated to eGFR [1].

First, it is worth noting that according to recent data, stage 2 CKD (eGFR $60-90 \mathrm{~mL} / \mathrm{min} / 1.73 \mathrm{~m}^{2}$ ), especially in patients aged on average 62 years, is considered as an artificial category derived from imperfections of the GFR calculation and not as true pathology; the same applies also to many older patients with CKD stage 3 . In this context there is no reason to expect any influence of kidney function on aspirin-induced platelet reactivity in CKD except from advanced renal failure as has been shown also by others [4].

A sharp increase in AR prevalence in CKD stage 4-5 may be related to profound metabolic disturbances of chronic uremia, although it is rather platelet dysfunction and uremic diathesis than increased risk of thrombosis that are more common in such patients [5]. Apart from multiple complex mechanisms of AR mentioned by Aksu et al. [1], a few other potential factors should be considered. Firstly, phosphate binders (calcium carbonate and citrate, lanthanum carbonate, sevelamer and - occasionally — aluminum hydroxide), commonly used in patients on haemodialysis (HD) and very infrequently administered in earlier CKD stages, could sub- stantially affect acetylsalicylic acid (ASA) bioavailability. This confounding factor has been not included in their analysis. We cannot exclude any interactions between ASA and phosphate binder use. Secondly, proton pump inhibitors (PPI) seem to be overused in dialysis population (more than $50 \%$ of subjects in some HD cohorts receive these drugs) and clinical data have suggested that PPI may attenuate antiplatelet effects of ASA [6].

The second important issue related to the work by Aksu et al. [1] is a benefit expected from the use of ASA in CKD. Indeed, post-hoc analysis of the HOT trial has shown that reduction in major CV events and hospitalisation associated with ASA use was inversely correlated with eGFR (with the highest benefit observed in patients with eGFR $<45 \mathrm{~mL} / \mathrm{min} / 1.73 \mathrm{~m}^{2}$ ). Bleeding complications were also increasing with loss of GFR, but did not offset CV benefits. There were however only 536 patients (out of 18,597 in the HOT trial) with this level of eGFR (mean $40 \mathrm{~mL} / \mathrm{min} . / 1.73 \mathrm{~m}^{2}$, interquartile range: 32-43, and no patients with CKD stage 4-5) [7]. Despite lack of convincing data, ASA is frequently prescribed to HD patients; a recent large epidemiological study has showed that $8 \%$ to $36 \%$ of HD patients (depending on a country) were using this drug [8]. Patients on HD have significantly higher risk of bleeding and aspirin use is associated with increased adjusted risk of mortality, or - at best - has no impact on outcome $[8,9]$. We are convinced that there is no reason to expect any long-term benefit from the use of aspirin in patients with advanced CKD in terms of CV end-points and mortality; the advantage of ASA is probably limited to longer patency of vascular grafts used as an access for HD [10]. We believe that data showing benefits from the use of ASA in secondary prevention cannot be extrapolated from the general population to subjects with advanced CKD. Although prevalence of $A R$ is high in this patient group, it would probably have very little impact on patient prognosis.

Conflict of interest: none declared 


\section{References}

1. Aksu HU, Oner E, Erturk $M$ et al. Aspirin resistance in patients with impaired renal functions. Kardiol Pol, 2014; 72: 331-338.

2. Opolski G, Strojek K, Kurzelewski M et al. Cardiovascular therapy, diagnostic procedures, and control of risk factors in patients with diabetes or coronary artery disease in Poland: the Kardia-Pol registry. Pol Arch Med Wewn, 2012; 122: 413-421.

3. Liew A, Darvish-Kazem S, Douketis JD. Is there a role for the novel oral anticoagulants in patients with an acute coronary syndrome? A review of the clinical trials. Pol Arch Med Wewn, 2013; 123: 617-622.

4. Würtz M, Wulff LN, Grove EL et al. Influence of renal function and platelet turnover on the antiplatelet effect of aspirin. Thromb Res, 2012; 129: 434-440.

5. Escolar G, Diaz-Ricart M, Cases A. Uremic platelet dysfunction: past and present. Curr Hematol Rep, 2005; 4: 359-367.
6. Würtz M, Grove EL. Combining aspirin and proton pump inhibitors: for whom the warning bell tolls? Expert Opin Drug Metab Toxicol, 2012; 8: 1051-1055.

7. Jardine MJ, Ninomiya T, Perkovic V et al. Aspirin is beneficial in hypertensive patients with chronic kidney disease: a post-hoc subgroup analysis of a randomized controlled trial. J Am Coll Cardiol, 2010; 56: 956-965.

8. Sood MM, Larkina M, Thumma JR et al. Major bleeding events and risk stratification of antithrombotic agents in hemodialysis: results from the DOPPS. Kidney Int, 2013; 84: 600-608.

9. Chan KE, Lazarus JM, Thadhani R, Hakim RM. Anticoagulant and antiplatelet usage associates with mortality among hemodialysis patients. J Am Soc Nephrol, 2009; 20: 872-881.

10. Dixon BS, Beck GJ, Dember LM; Dialysis Access Consortium (DAC) Study Group. Use of aspirin associates with longer primary patency of hemodialysis grafts. J Am Soc Nephrol, 2011; 22: 773-781.

\section{KONFERENCJA NAUKOWA POLSKIEGO TOWARZYSTWA KARDIOLOGICZNEGO}

SEKCJA WAD ZASTAWKOWYCH SERCA POLSKIEGO TOWARZYSTWA KARDIOLOGICZNEGO

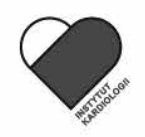

Instytut Kardiologii

IM. PRYMASATYSIACLECIA

STEFANA KARDYNAŁAWYSZYŃSKIEGO

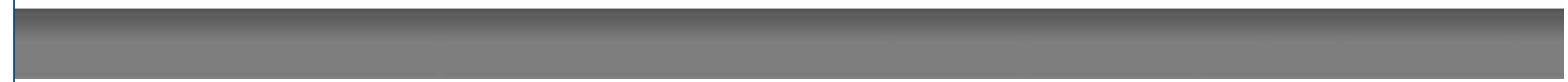

Sekcja Wad Zastawkowych Serca

Polskiego Towarzystwa Kardiologicznego

serdecznie zaprasza na

KONFERENCJĘ NAUKOWĄ

która odbędzie się

4 października 2014 roku

w Instytucie Kardiologii im. Prymasa Tysiąclecia Stefana Kardynała Wyszyńskiego

(ul. Alpejska 42, 04-628 Warszawa; zespół konferencyjny)

Tematy konferencji:

- IZW - obrazowanie, antybiotykoterapia, leczenie chirurgiczne

- Operacja czy leczenie przezskórne - przecieki okołozastawkowe, TAVI, MitraClip...

- $\quad$ Problemy interdyscyplinarne w wadach zastawkowych

- Nowe technologie...

- Wady zastawkowe u dzieci, młodzieży, młodych dorosłych

- Hotline, nowości...

Zaproszenie do udziału w konferencji przyjęli m.in.:

G. Brzezińska-Rajszys, M. Deja, M. Demkow, Z. Gąsior, T. Grodzicki, P. Hoffman, T. Hryniewiecki,

M. Jasiński, M. Komar, M. Kuśmierczyk, T. Kukulski, P. Łuków, B. Maruszewski, K. Mizia-Stec,

M. Myśliwiec, P. Pysz, T. Pasierski, E. Płońska-Gościniak, J. Różański, W. Rużyłło, G. Smolka, P. Szymański,

L. Tomkiewicz-Pająk, O. Trojnarska, B. Werner, K. Widenka, A. Witkowski, B. Zaborska, M. Zembala

\section{Szczegółowy program i rejestracja na stronie: www.konferencjaswzs.pl}

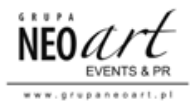

